\title{
Ethnic Conflicts and Internally Displaced Persons in Rumuekpe and Igwuruta Communities of Rivers State, Nigeria
}

\author{
Blessing O. Edafe ${ }^{1}$ \\ Kingsley E. Okoye ${ }^{1 *}$ \\ Paulinus O. Agbo ${ }^{2}$ \\ ${ }^{1}$ Department of Political Science, University of Nigeria, Nsukka, Nigeria \\ ${ }^{2}$ Department of Religion and Cultural Studies, \\ University of Nigeria, Nsukka, Nigeria \\ *Corresponding author
}

DOI: https://doi.org/10.36941/jicd-2021-0016

\section{Abstract}

The return to democratic dispensation and the surge to acquire political power had led to increase in violence in the Niger Delta region. This assumed different dimension for national issues as competition for scarce resources are being instigated by "inter-elite" rivalries over contradictions of ethnic diversity. These incessant struggles and the competitions had resulted into outright denial of people's right and privileges as well as displacement of indigene and non indigene in that area. The study contended that the dynamics of internally displaced persons in the Niger Delta region were deeply rooted in the contradictions of ethnic diversity. The study is a documentary research and data were analyzed through qualitative descriptive method. Using human needs theory, the paper noted that, the need for the IDPs to be fully re-integrated into society, and the responsibility of public authorities to avoid neglect, discriminatory practices of marginalization, deprivation as well as the exploitation of the indigene non-indigene issue. It is urgent to meet the social needs of the IDPs, and their recognition and social inclusion into the society in the Rivers state, for peaceful coexistence in assuring freedom for the development of people. The study therefore recommends the following that government should ensure that specific needs of internally displaced persons are reflected in the national and local developmental plan.

Keywords: National Question, Internally Displaced Persons, Deprivation, Indigene-Non-Indigene, Ethnic Diversity 


\section{Introduction}

The problem of heterogeneous societies in the world stirs up mutual distrust and intra and inter community conflicts. This has not only become recurrent and widespread but has made Nigerian politics unfavourable since independence. The apprehension of power of one tribal or cultural group of the country by another arising from "who gets what, when and how" constitute a major factor of this problem (Agbodike 1998).These ethnic groups are broadly divided into ethnic "majorities" and ethnic "minorities" (Otite, 2000) with indigenous religious beliefs and practices. Being a plural society and heterogeneous state, Nigeria has been composed of different ethno-cultural and religious groups with the attendant fears and suspicions of domination and feeling of exclusion among these groups. These untoward patterns of relationship do not only engender exclusion and alienation of some groups from the country's politics but also serve as a major source of frustration responsible for conflict in the society. Rhodes (2002) posits that, displacement affects communities beyond the individuals who are themselves displaced. It is the duty and responsibility of the state to ward off arbitrary displacement and defend or assist those who have been displaced.

Imperatively, Nigeria like many other states in Africa had experienced problems that could be linked to ethnic conflicts which took the form of colonial rule, military rule, political conflicts, civil war etc, Thus, these contradictions in the country's polity, including the interventions of the military, gave way to what stood out as the most brutal civil wars in Africa in the second half of the twentieth century. No doubt, all these have a way of instigating internally displaced persons (IDPs). However, it is worthy to note that internal displacement has occurred in 'Nigeria 54 years ago', when, during the Biafran war (1967-1970) some two million people died and ten million people became internally displaced (Ibeanu, 1998). And despite the current surge of internally displaced persons in the North, the current figures cannot be compared to the post- civil war crises. Since then, internal population displacement has been on the increase. Thus, with the resultant effect of the Nigeria civil war, large numbers of people in Rivers State, Igwuruta were uprooted from their habitual place of residence, in correspondence of the establishment of "Abandoned Property Act". While displacement of this number has not repeated itself since then, millions have been internally displaced due to religious and ethnic conflicts particularly in cities across the north.

It is instructive to note that, in the aftermath of the civil war; Nigeria became characterized with struggle and resistance against the state system in various forms, in a violent ways. The tussle against the perceived injustices by various groups has resulted into widespread infrastructural damage and innumerable human casualties since the post-independence era (Agbo, Okoye, Uwaegbute, \& Agbo, 2021). Synder (1993) therefore maintain that, the failure of the post-colonial state in Nigeria to meet its socioeconomic obligation of the people has encouraged the festering of primordial segregation among these groups. A system that is characterized by these basics 
instigates uneven relations among her citizens. The problem associated with this kind of disparity is that some individuals are deprived of some political and economic rights as preserved in the country's legal framework. The effect arising from such deprivation is that these individuals are excluded from participating in the political and economic activities in their community. This awkward prototype of association only engenders exclusion and alienation of some groups from the mainstream society and it is a major source of frustration responsible for and igniting conflict (Albert, 2015). Hence, one of the key features of the nation polity in addressing these raucous agitation and conflicting ideas of the diverse ethnic groups, minority communities, and other disadvantaged groups seeking for their inalienable rights is widely referred to as the "National Question", wherein ethnic minority tensions, agitations and marginalization are fundamental features of the ongoing struggles that revolves around the "National Question" for decades.

Thus, the preponderate proclivity of different studies is to perceive the increasing surge of internally displaced persons as the inability of the state to checkmate its excesses. Issues relating to human rights abuse, poor articulated policies, political volatility, and poor infrastructural facilities to the citizens are usually responsible for the crisis (Ibeanu, 2001a). Therefore; the system produces and sustains a hierarchical, unequal, and ranked system of citizenship that has provoked exclusion, marginalization and segregation of individuals. Although these identities have grown in significance in the recent past, which obviously has to do with the aggravation of the "ethnic conflict", which have deep historical roots in pre-colonial patterns of inter-group relations, and the discriminatory practices and ethnic inequalities entrenched by both the colonial regime, continued by post-independence administrations. These have cumulatively provoked various forms of self-determination agitation by different groups (Osaghae \& Suberu, 2005).

Ethnic conflict being a principal factor in addressing basic societal problems, Ibeanu (2001b) noted that the state becomes a tool used in place of regional, ethnic, religious, class, clan and other sectional benefits. It has become intensely involved in the struggle for adherent support of some groups against others. The state equally seems to be authoritarian in character, given the enormous power it possesses within its base. In this regard, the Nigeria state is marred in social struggle, the state nonetheless failed to know how the internal displaced persons integrate into the environment, and create relationship with the host communities. In spite of the tendency on the part of the Nigerian state to conceal internally displaced populations, their existence still remains a serious problem (Ibeanu 1998). It can be deduced that the Nigeria state has been accompanied with unresolved issues and therefore, it is pertinent to note however, that the failure of the state to address these issues, have led to the resultant effect of neglect. At this point, the internally displaced persons appear to be the most critical component of the national question in Nigeria. Owing to these facts, some of the minority groups (Rumuekpe and Aro in Omuchilgwuruta) still believed that they have 
been deprived and excluded in the society due largely on the failure of the Nigeria state to discharge its responsibilities as demonstrated in its inability to cater for its citizenry that were involved in identity alienation.

Against this backdrop, this study seeks to examine the nexus between the issues of ethnic conflict and the problem of internally displaced persons in the Niger Delta, through narrative profiles of two selected communities' in Ikwerre, Rivers State.

\section{Theoretical Framework}

Human Needs Theory (HNT) was adopted as our theoretical framework for analysis in this work. Its adoption was based on what it represents in conflicts. This theory was inclined to streamline the exigencies of ethnic conflict and the internally displaced persons. Though, this consideration was not for its inherent vigor and understanding, but also for the wide-ranging and enduring nature of its supposition, given that man's intrinsic need to rule by all means possible is being considered to be essential in his peace and happiness. Human Needs Theory (HNT) was developed in the 1970s and 1980 s as a holistic theory of human behavior. Given the different behaviours peculiar or attributed to man, the theory was premised on the foundation that a certain basic needs of man is assumed to be met in order to preserve stable societies. Scholars like Abraham Maslow, John Burton, Marshall Rosenberg and Manfred Max-Neef are known to be the proponents of the theory. As Burton states:

It is expected that the human relationships among people at all social levels are geared towards the satisfaction of their primordial and universal needs such as security, identity, recognition and development. Inadvertently, they engage in such struggle in order to have firm control over their environment which will guarantee the satisfaction of these basic needs. This strive is inevitable as it works with individual identities (Burton, 1990).

Accordingly, the theory shows that humans react aggressively whenever they are denied of their basic needs. These basic needs include physical, psychological, social and spiritual, etc. It shows that an attainment to one of these needs is likely to deny access to the provision of another. For instance, an achievement to freedom of human dignity could make people act differently thereby instigating violent. Some prominent needs of the theories include Maslow's theory of Motivation, Burton's Human Needs theory, Gurr's thesis on Relative Deprivation, etc (Faleti, 2007). Human Needs Theory, therefore, is the understanding that violent behavior and clashes are the consequences of some challenges found in our institutions and social norms resulting from incompatibility with innate abilities to satisfy human needs.

In this regard, human needs theorist assert that one of the primary causes of lingering or intractable conflict is peoples firms strive to achieve their unachievable needs on the part of an individual, group, and at the societal level. Consequently, Human Needs Theory present insights to a wide range of peace building processes that 
are involved in distributive justice system (Hauss, 2003), in order to live and attain wellbeing, by giving more importance to these needs, which are essential to the wellbeing of individuals in the society. The dissatisfaction and aggrieved nature of these individuals will inadvertently make them to seek for governments' intervention for more just and equitable accommodation to them. This could account for why Marker (2003) saw Human Needs as non-negotiable.

Human Needs Theory to ethnic conflicts and the problems of internally displaced persons, involved needs based on citizenship rights for belonging, right to security of lives and property, identity, justice and integration into the society. In the application of this theory to ethnic conflicts and the problem of internally displaced persons in an ethnically diverse society, it enhances a common knowledge about humanity and the differences between negotiable and non-negotiable issues. Whether the human needs was satisfied, and the task of satisfying these needs is to develop new methods of understanding and satisfying them. In a world context where differences are accentuated in the national question and internally displaced persons in Rivers State, in the case of Rumuekpe and Aro (Omuchi) Igwurita Ikwerre, what these group are demanding for justice based on citizenship right in affirmation to the national question as Ismagilova (1978) pointed out, that the national question includes the elimination of all outward appearance of ethnic domination and disparity.

This notwithstanding, the ultimate aim of the Human Needs Theory to the crises of ethnic conflicts and the neglect of internally displaced persons in the region, established real equality, friendship, and fraternal cooperation with peoples that aims at the abolition of the exploitation of a region by the other to bring about equity and justice, to create the sense of belonging on the peoples of the region and to foster national integration. These problems were made more acute because these groups believed that they have been denied exclusively of their basic needs in terms of deprivation of belonging in the community and as well as the failure of the state to meet their needs. With its application in the restorative justice, it is pertinent in identifying what these needs are; needs for sense of belonging, justice, participation, inclusion and identity. Since human needs are essential to life, the social struggle as how these groups relates in the society and state determines their struggle for identity, justice, survival and integration. Similarly, since the Human Needs Theory strike the right balance between the ethnic conflicts and the problems of Internally Displaced Persons, a central issue is the group security: security of livelihoods, food security, and security of identity, environmental security and, above all, physical security (Ibeanu, 2001b). Insecurity occasioned by conflicts is detrimental to life.

\section{Ethnic Diversity in the Niger Delta Region of Nigeria}

As a multi-ethnic, multilingual and multi-cultural society, the Niger Delta area is characterized by ethnic pluralism comprising over 20 different ethnic and sub-ethnic 
groups as inhabited by ljaw, Itsekiri, Urhobo, Bini, Isoko, Ukwuani, Ibibio, Efik, Anang, Ogoni, among others. Many of these ethnic groups traced their origins to the Yorubas, Igbos, Edos and ljaws. These groups constitute the five major linguistic and cultural groups in the region (Ikime, 1972; Otite, 2000). Based on the 2006 census, the population of the people in the Niger Delta is over 30 million. Among the ethnic groups in the region, the ljaw, who are distributed among six states of the Nigerian federation, constitute the largest single ethnic group in the region and the fourth largest in the country.

Given its natural location, multi-ethnic, multilingual and multi-cultural character, the Niger Delta is no stranger to inter and intra communal conflicts. The region is heterogeneous and multi-culturally diverse area of 7,000 square Kilometers (Tamuno, 1999). There are several inter and intra communal conflicts witnessed in the region due largely to the unnecessary competition for access to limited resources. Many of such communal conflicts were resolved through the intervention of the government. Therefore, the feeling of marginalization by some of these ethnic groups (minority groups) in the Niger Delta in the fair share and allocation of the nation's resources was adduced to be the basis for inter-ethnic crises in the country.

Furthermore, Niger Delta viewed as an ideal type of a heterogeneous and plural society divided along ethnic, tribal and religious identities lumped together. The region has been enmeshed in conflicts, violence and terror associated with its heterogeneity and diversity. Imperatively, Odoemene (2008) conception of ethnic diversity has been a very powerful force in the socio-economic politics of Nigeria, and is more fervently exhibited within the indigene-settler dichotomy. The term 'indigene-ship' is still practicable within the country's ethnic diversity. As Plotnicov (1972) notes, "Owners of the land" is a statement extensively used to assign the natives of a particular place, even when they are not original owners of the land. Nonetheless, apart from being a constitutive component of inter-group politics, ethnicity also has transformative tendencies, which could produce conflict as well as cooperative outcomes (Du Plessis, 2001).

Consequently, Ethnic diversity, the albatross of many nations, has caused conflicts and wars all over the world leading to various forms of displacement. It has hindered the sustainable development of the culture of peace and equity in Nigeria. In the case of the IDP's in (Aro camp of Omuchi) Igwuruta, Ikwerre which is our focus, it is still absorbing to see how ethnic divide and bitterness has played out in present day Rivers State. The pattern adopted by the people of Rivers was "Abandoned Property" controversy, which made Igbos to seize their pre-war properties that left hundreds of people displaced in Igwuruta for decades. In attempt to reclaim their communities, the people (Rivers) have conscientiously prefixed the name of some of their towns belonging to the Igbos. Subsequently, "Umuigbo" is "Rumuigbo", "Umomasi" is now "Rumuomasi", "Umuobiakani", is "Rumuobiakani", "Umukurushi" is "Rumukurushi" (Effiong, 2012).

The resultant effect of the civil war that lasted for almost three years, 1966-1970 
left devastating effects in the mind of the Aro's IDP's of Omuchi which had led to displacement in the Rivers States. This displacement forced the returnees of the civil war to abandon their ancestral homes and "Co-habit" their relatives. A scenario that is not only disgusting but had led to more challenges in the Niger Delta region of the country. Government of each states in which properties were abandoned, enacted laws to relinquish the rights, of the property owners. After the civil war, the federal government of Nigeria also enacted the Abandoned Property Act, 1979, Cap 1, law of the federation of Nigeria, 1990, respecting to abandoned properties in all the states of the federation. Old Rivers and Old Cross Rivers States used the term "Abandoned Properties". The issue of abandoned properties became a national problem in the sense that after the war they returned back to Rivers State to start up a new life, only to discover that they have been deprived of their property. This has remained one of the unresolved issues after the civil war.

\section{Internally Displaced Persons in the Niger Delta}

Internally displaced persons in the Niger Delta can be viewed within the context of the civil war, oil violence militancy, environmental degradation and inter and intra communal violence. Sequel to the displacement of people in the Niger Delta, there is limited capacity of the Nigeria state to ascertain the actual figure of the displacement pattern. Internally displaced persons in the Niger Delta region is associated to conflict over the distribution of rural projects, elections result crisis and conflict arising from crude oil exploration in the region. Arguably, environmental conflict in the Niger Delta constitutes the most important cause of IDP's not only within the region, but also other parts of the country. Conflict-triggered internal displacements of persons in Nigeria are a recurrent phenomenon caused by communal violence, irrespective of the causes. A dominant perspective on internally displaced persons spearheaded by Kunz, (1973) \& Suhrke (1983) respectively associates the problem with one of forced or involuntary migration. For them, internally displaced persons are subject to what they described as "force-subject migration" calculation. In other words, people flee their homes due to no decision of theirs; they are circumstantially coerced by virtue of the consideration for safety to relocate to other places within the territorial boundary of the state where they take residence.

In social relation terms, Ibeanu (1998) raised the following concerns, firstly; the key factor in any population displacement is group security: under this, he highlighted issues like security of lives and properties, food security, environmental and identity security. Secondly; conflict in his analysis is a major issue towards understanding and analyzing displacement. This he noted that opposition of group interests intrinsic in population displacement indicates that social rivalry could lead to physical conflicts or violence, particularly wars. When this occurs, displacement takes place (Ibeanu, 2001b). However, Ibeanu (1998), observed that displaced people rarely contest and only in few celebrated 
cases in which he mentioned the Ogonis whose oil exploration had brought hardship to the people living therein. Owing to fears about access to resource, forced displacement in the oil-producing communities invariably triggered conflicts within these communities as a result of power tussle. This tussle continued and finally became a war that caused large trunk of displacements. More so, the attendant conflict in the region between 2003 and 2008 of Rumuekpe was engrossed in an unprecedented and deadly intra communal clash that claims the lives of hundreds of innocent citizens of the community, with many more, including the aged ones, displaced. In September 2008, some of the heaviest clashes in the region between the military and members of the Movement for the Emancipation of the Niger Delta (MEND), civilians were caught in the crossfire and two villages were allegedly razed to the ground forcing up to 20,000 people to flee (IRIN, 2008).

Some of the eminent factors that have forced people to leave their homes include violence between local militia groups and security forces, inter-militia fighting and widespread destruction of property (Reuters, 2008). Oil-related environmental problems in the area have also been linked to increased population movements. Inter-communal conflicts and clashes between the army and militia members in the Niger Delta continued to be the main direct causes of displacement in 2008. In Bayelsa for instance, the Ewama community of about 8,000 persons have been displaced for 10 years, following the total destruction of the town by Okpoama community, over chieftaincy dispute (Opukri \& Ibaba, 2008). In Delta State, the ljaw-Itsekiri conflict, which resulted from the relocation of Warri South Local Government headquarters from Ogbe-ljaw to Igidigben, displaced thousands of people on both sides. The displacement of people and villages when oil spillages occur is another social problem occasioned by the oil industry. The displacement of Igolu village in Isoko land were resulted from the massive spillage in 1973 at Shell's location had untold physical and psychological impact on the people as well rendering them displaced. In the same vein, the September 1999 oil spillage disaster at Ekakpamre also in Delta State impacted on the people negatively. In Rivers state for over 10 years, youth leadership tussle and chieftaincy title right in Rumuekpe caused hundreds of thousand people to be displaced. These entire events therefore show that displacement is inevitable in the Niger Delta. From the above, it is expedient to note that conflict is generally a dominant cause of internal displacement. The question is, to what extent has the ethnic conflicts been able to address these issues of IDP's in the Niger Delta region.

\section{Material and Method}

The study adopted the survey design, Kerlinger (1973), considered survey research as social scientific research that focuses on people, the vital facts of people, and their beliefs, opinions, attitudes, motivations and behavior., in order to test our hypotheses, the study utilized both primary and secondary data. In line with the survey design we 
therefore involved descriptive research used for the collection of data from the representative sample of the target population. Descriptive research is concerned with the accurate description of the variables in the problem formulated and causal research specifies the functional relationship between the variables in the problem formulated. In the same vein, the present study has a cross sectional research design in the sense that observation was done at various points in time in observing what is happening to sample subjects or variables without any attempt to manipulate or control them using descriptive design (Asika, 1991). This type of design involves the observation of the sample or cross-section of a population/phenomenon which are made at some point in time (Babbie, 2007). Cross-sectional survey design is usually adopted in both exploratory and descriptive research.

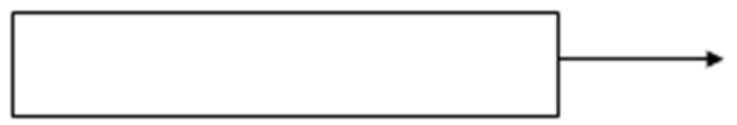

$$
-\mathrm{X}_{1},-\mathrm{X}_{2},-\mathrm{X}_{3},-\mathrm{X}_{\mathrm{n}}
$$

Where: $\mathrm{X}$ is the independent manipulable variable that is not manipulated.

To Asika (1991), the descriptive involves one-time observation of independent and non-manipulated variables. We applied the self-report technique of data collection in generating information from the IDPs of Igwuruta, (Aro camp in Omuchi community), and Rumuekpe. The primary data were obtained through questionnaires, Oral interviews and focused group discussion (FGD) sessions were deployed to source primary data for the study with some of the community indigenes and residence in the study sites which are Igwuruta and Rumuekpe, in Ikwerre, Rivers states who experienced the displacement and who were knowledgeable on the displacement in these communities. We equally conducted unstructured interview with the president and secretary of these communities. The questionnaire was designed in such a manner that it contained both open-ended and closed-ended questions in order to enable the respondent's to air their opinion on the subject of the study to ensure that the fullest possible data were generated.

The study was carried out in Igwuruta (Aro camp in Omuchi community), and Rumuekpe, Rivers State where a total of 8,188 internally displaced persons are found in both communities. At the time of this study the population of IDPs in Igwuruta (Aro camp in Omuchi community), was estimated to be six hundred and eighty eight (688) by the secretary, and that of Rumuekpe seven thousand and five hundred (7500) persons. Therefore, the study make use of Purposive and snowball sampling methods was used and data was collected from a sample of three hundred and sixty-seven (367) IDPs, comprising of the leaders and secretary of the camp and community to reach other IDPs. The study used purposive sampling because the researcher wanted to interview people who were relevant to the research question (Brymann, 2004). Henning (2004) maintains that purposive sampling and snowball sampling are related and have one common 
denominator: "the people most suitable to 'wander with' on the research journey are selected at the time they are needed". Fifteen people were interviewed during the elite interviewer session and were purposely selected by the researcher based on the position, knowledge and experience on the topic of research. The participants consist of IDPs and host communities. The idea was to get them to describe and discuss their experiences of the conflict that lead to the displacement. The sampling population was chosen from the community level, the participants represented individuals who were investigated according to problem formulation. The two target communities included Aro camp IDPs living within the hosting community premise of Omuchi community in Igwuruta, and Rumuekpe, in Rivers states. Four FGDs session were conducted; 2 sessions in Igwuruta (Aro community camp in Omuchi community), and 2 sessions in Rumuekpe with sample sizes of 6, 8 and 7, 6, respectively. The Focus Group Discussion (FGD) guide was used as a supportive instrument to explore IDP's opinion towards the neglect and marginalization. Therefore a total of 27 respondents participated in this study. As can be seen, the discussants that constituted the groups vary. The standard number adopted for the study was seven but in case where the target could not be achieved, 6 were made the minimum.

In this study, a multi-method approach was used. Data gathered from observations, focus group discussion; individual interviews and document analysis supplement each other as part of data analysis. We made use of the descriptive and inferential statistics to analyze data from questionnaire. Descriptive statistics like percentages and frequency tables were used in characterizing respondents. Chi-square $\left(\mathrm{X}^{2}\right)$ was also used to determine the frequency tables and percentages adopted in the analysis of the qualitative data, emphasis were placed on the interpretation of written document. Since both our research question and hypotheses border on the test of significance the use of chi-square is justified.

\section{Results}

This section contains data presentation and analyses of the findings from the survey conducted, followed by data computation. Further, the section is concerned with the empirical verification of our research hypothesis.

Table 1: Community Distribution of Respondents

\begin{tabular}{|lccccccccc|}
\multirow{2}{*}{ Community } & \multicolumn{2}{c}{ Returned completed } & Returned uncompleted & \multicolumn{2}{c}{ Not Returned } & \multicolumn{2}{c}{ Total } \\
& Frequency & Percentage & Frequency & Percentage & Frequency & Percentage & Frequency & Percentage \\
\hline Rumuekpe & 380 & 72.09 & 8 & 2.43 & 9 & 3.21 & 395 & 76.50 \\
\hline Igwuruta & 215 & 23.06 & 3 & 0.32 & 6 & 2.13 & 217 & 23.50 \\
\hline Total & $\mathbf{5 9 5}$ & $\mathbf{9 5 . 1 5}$ & $\mathbf{1 1}$ & $\mathbf{2 . 7 5}$ & $\mathbf{1 5}$ & $\mathbf{5 . 3 4}$ & $\mathbf{6 1 2}$ & $\mathbf{1 0 0}$ \\
\hline
\end{tabular}

Source: Field Research, 2020 
The table above shows the order in which the questionnaires were distributed to the various communities sampled. Out of the 612 questionnaires distributed, 395 were given to Rumuekpe which represent $76.50 \%$. However, 390 were returned; out of which 380 representing $76.50 \%$ were duly completed; while 6 representing $2.13 \%$ were inappropriately completed and were considered unsuitable for the study. Besides, 9 representing 3.21\% were not returned. On the other hand, 217 questionnaires were administered in Igwuruta (Aro camp in Omuchi community) representing $23.50 \%$ of the sample. However, 216 were returned, out of which 215 representing $23.06 \%$ were duly completed, while 3 representing $0.32 \%$ was inappropriately completed thereby making them unsuitable for the study; while 5 representing $1.36 \%$ were not returned. Hence, a total of 600 were sent back and appropriately completed. In total, 600 representing $94.82 \%$ approximately $95 \%$ were returned from both communities duly completed.

The study therefore made use of a total of 600 duly completed and returned questionnaires. According to Bailey (1982:165) a response figure of at least fifty percent $(50 \%)$ should be sufficient for analysis of data, a figure of sixty percent $(60 \%)$ can be seen as "good" and a figure of seventy percent (70\%) can be seen as "very good". It is clear from table 2 above that the research had a good response rate at $95 \%$ response rate. Thus, we have a high degree of confidence in the representativeness of the survey.

\section{Hypothesis One:}

The crises of Ethnic Conflicts in the Niger Delta region accounts for the neglect of internally displaced persons in the region.

Table 2: Was there a problem with the management/treatment of Internally Displaced Persons (IDPs) after the conflict?

\begin{tabular}{|l|ccccccc|}
\hline Community/Response & \multicolumn{2}{|c}{ Rumuekpe } & \multicolumn{2}{c|}{ Igwuruta } & \multicolumn{2}{c|}{ Total } \\
& Frequency & Percentage & Frequency & Percentage & Frequency & Percentage \\
\hline Yes & 345 & 68.55 & 89 & 29.26 & $\mathbf{4 . 5 4}$ & $\mathbf{9 5 . 7 2}$ \\
\hline No & 6 & 1.23 & 3 & 0.46 & $\mathbf{6}$ & $\mathbf{2 . 2 5}$ \\
\hline Undecided & 12 & 3.76 & 7 & 1.52 & $\mathbf{1 6}$ & $\mathbf{6 . 0 2}$ \\
\hline
\end{tabular}

Source: Field Research, 2020

Information in this table revealed that $68.55 \%$ in Rumuekpe and $29.26 \%$ in Aro camp in Omuchi Igwuruta representing a sum of $95.72 \%$ agreed that there was a problem with the IDP's treatment after the conflict. They argued that there was total neglect of the IDP's by the government while $1.23 \%$ in both communities responded no to the question and $6.02 \%$ in both Rumuekpe and Igwuruta were unable to decide if there was such a claim to the above question. 
Table 3: Do you think IDPs should be given the right to participate in the social and political process in a community where they found themselves different from their habitual place of residence?

\begin{tabular}{|lcccccc|}
\multirow{2}{*}{$\begin{array}{l}\text { Community/Response } \\
\text { Yes }\end{array}$} & \multicolumn{2}{c}{ Rumuekpe } & \multicolumn{2}{c|}{ Igwuruta } & \multicolumn{2}{c|}{ Total } \\
& Frequency & Percentage & Frequency & Percentage & Frequency & Percentage \\
\hline No & 161 & 43.46 & 65 & 16.25 & $\mathbf{2 3 4}$ & $\mathbf{5 6 . 7 8}$ \\
\hline Undecided & 92 & 30.00 & 48 & 13.22 & $\mathbf{1 3 8}$ & $\mathbf{4 6 . 2 3}$ \\
\hline
\end{tabular}

Source: Field Research, 2020

Table 3 shows that $56.78 \%$ respondents in both communities asserted that IDP's should be given the right to participate in the social and political process in the community where they found themselves, $46.23 \%$ did not, while $11.94 \%$ were undecided in their responses.

\section{Chi-Square Table}

\begin{tabular}{|ccccc|}
\hline & Yes & No & Undecided & Iof \\
\hline Of & 196 & 145 & 47 & 600 \\
\hline Ef & 124 & 124 & 124 & \\
\hline
\end{tabular}

Significant, $p=0.05$

Since the calculated value (93.17) at $5 \%$ level of significance and degree of freedom (df) is greater than the tabulated value (3.84), we therefore, reject the null hypotheses $\left(H_{0}\right)$, and accept the alternative hypotheses, which state that the crises of National Question in the Niger Delta region has not accounts for the neglect of internally displaced persons in the region.

Hypothesis Two: The ethnic diversity character of the Niger Delta region is implicated in the problem of internally displaced persons in the region since the civil war.

Table 4: Any form of challenges/abuse in terms of victimization/marginalization?

\begin{tabular}{|lccccccc|}
\hline \multirow{2}{*}{ Community/Response } & \multicolumn{2}{c}{ Rumuekpe } & \multicolumn{2}{c}{ Igwuruta } & \multicolumn{2}{c|}{ Total } \\
\cline { 2 - 8 } & Frequency & Percentage & Frequency & Percentage & Frequency & Percentage \\
\hline Yes & 425 & 75.00 & 124 & 32.00 & $\mathbf{4 6 5}$ & $\mathbf{9 4 . 3 0}$ \\
\hline No & 00 & 0.00 & 00 & 0.00 & $\mathbf{0 0}$ & $\mathbf{0 0 . 0 0}$ \\
\hline Undecided & 14 & 4.18 & 05 & 0.69 & $\mathbf{1 7}$ & $\mathbf{4 . 8 5}$ \\
\hline
\end{tabular}

Source: Field Research, 2020 
The table 4 above shows that $94.30 \%$ of the respondent agreed that they were been biased in the community, $0.69 \%$ of the respondents disagreed, while $4.85 \%$ were undecided in their responses in both communities.

Table 5: Has there been any form of segregation of the IDPs in the community?

\begin{tabular}{|lccccccc|}
\hline \multirow{2}{*}{ Community Response } & \multicolumn{2}{c}{ Rumuekpe } & \multicolumn{2}{c|}{ Igwuruta } & \multicolumn{2}{c|}{ Total } \\
\cline { 2 - 8 } & Frequency & Percentage & Frequency & Percentage & Frequency & Percentage \\
\hline Yes & 342 & 77.47 & 97 & 32.16 & $\mathbf{4 6 1}$ & $\mathbf{9 7 . 3 3}$ \\
\hline No & 7 & 3.48 & 6 & 2.17 & $\mathbf{1 5}$ & $\mathbf{4 . 6 3}$ \\
\hline Undecided & 6 & 0.63 & 2 & 0.36 & $\mathbf{3 0}$ & $\mathbf{0 . 7 9}$ \\
\hline
\end{tabular}

Source: Field Research, 2020

The information from the above table shows that $97.33 \%$ respondent are of the view that, they were segregated; $4.63 \%$ disagree with the question while $0.79 \%$ tentative of the responses. The various responses of the group discussion in Aro camp in Igwuruta give plausibility to the responses that their residential segregation poses a secondary tier of social exclusion. That ethnic segregation does affect their access to opportunities in the community.

Chi-Square Table

\begin{tabular}{|ccccc|}
\hline & Yes & No & Undecided & Iof \\
\hline Of & 284 & 167 & 49 & 430 \\
\hline
\end{tabular}

Significant, $p=0.05$

Since the calculated value (77.68) at $5 \%$ level of significance and degree of freedom (df) is greater than the tabulated value (4.84), we therefore, reject the null hypotheses $\left(H_{0}\right)$, and accept the alternative hypotheses, which state that ethnic diversity character of the Niger Delta region is not implicated in the problem of internally displaced persons in the region since the civil war.

\section{Discussion}

The basic argument of the study is premised on the fact that the problem of IDP's in the Niger Delta region has become a fundamental issue of the national question in addressing the peculiarity encountered in the region. The study therefore argues that the problem of internally displaced persons in Rivers State is as a result of the wrong institutionalization of policy by the state and poor state management. Hence, the deformities of the state and federal system has necessitated the neglect and deprivation 
of the people and the agitation is hinged on the assumption that the state could release the necessary resources needed for the development of these IDP's in the state. Therefore, social displacement where minority right is been accentuated is the cause of dissatisfaction and the aggrieved group is denied of social equilibrium of accommodation. It is instructive to note that with the differentiation of group interest, there is spatial separation of social exclusion of IDP's in the community where they found themselves. And in a situation whereby some groups are alienated from the society of not being an ancestral home called to be an indigene of the land, they are socially, politically and economically segregated, inactive participation due to an ethnically biased system whereby the right to actively participate in a community is denied for an inclusionary right to succession of indigene-ship. Therefore, there is bound to be a fragmentation of marginalization, alienation and social exclusion.

Imperatively, we can boldly state that National Question has not been able to remedy the problem of IDP's in Nigeria, in the sense that these groups are not integrated where they found themselves in other community order than theirs, deprived of their social needs. Similarly, in order to grapple with the issue of ethnicity in the Niger Delta region, IDP's has been a fundamental consequences of an ethnically diverse region in connection to Caldderon (2010) affirmation, that suggested that, displacement typically brings diversity to a community, which may not be necessarily welcomed to the host community. In addressing the main research questions of the study, therefore revealed the narratives of belonging, of return to the original place of residence and of identity. While these IDPs strive to be perceived as the same members of the local society, rejecting labeling themselves as "displaced", at the same time, they acknowledge that they don't belong were they are but elsewhere. Hence, from the study, the result of our findings validated the hypotheses of the study. However, in the findings, this study shows that IDP's status separates internally displaced persons from other co-citizens by social markers and thus gives them a certain identity.

Nevertheless, one of the most dominant narratives among IDPs was related to the sense of segregation and stigmatization generated by the local community. It is important to note that in most narratives of the interviewees the experiences of marginality are present, though the form of the responses is different. The IDP's label distinguishes their collective identity from the rest of the population and thus highlights their disconnectedness from the locals. Despite the co-ethnicity with their hosts they are differentiated, not just by dispossession and exile, but by the current dwelling type. Living in the collective centers creates certain stigma of temporariness. The segregation once again draws the boundary line between locals and IDP's and intensifies the margins between "us" and "them" and thus strengthens the IDP's sense of connectedness to the displaced population. The Nigerian state has become an instrument used to pursue regional, ethnic, religious, class, clan and other special interests. As a result, it has become deeply embroiled in social struggles as an instrument of some groups acting against others. In particular, it has become authoritarian because the groups that 
control it resist demands to broaden the base of power and participation in it (Ibeanu, 1993 p. 3; Okoye, et al, Forthcoming). This has had a profound impact on the character of conflict. Conflict and insecurity characterized by state violence constitute a principal factor in population displacement in Nigeria.

\section{Conclusion}

The work argues that government should take necessary steps to stop the discriminatory practice of the IDP's that has settle in a given community and the minority question of separation of not belonging should be eroded and as well meeting the need of these deprived group. The ethnic group differences in Nigeria have therefore contributed to the deepening crisis of the Nigerian state. The true character of the Nigerian state made it possible that its elite have contributed immensely to these challenges. This could explain why many of the policies established to solve the problems failed. It needs to be underscored that the impact of internally displaced persons extends beyond those displaced to disrupt whole communities and societies. Therefore, for the desired unity and peaceful integration and progress to be attained in Nigeria, the State must deal with issue of ethnicity, discrimination by "indigene" against "non- indigene" while doing more to restructure the polity.

\section{References}

Agbo, P., Okoye, K., Uwaegbute, K., Agbo, C. (2021). From Nigeria/Biafra War to increasing Ethnic Conflict: the imperative of Nehemiah's Administrative Strategy 18(1) 91 - 114. DOI: https://doi.org/10.31920/2516-5305/2021/18n1a5

Agbodike, C.C (1998) "Federal Character Principle and National Integration" in Kunle A. et.al, Federalism and Political Restructuring in Nigeria. Ibadan; Spectrum Books Ltd.

Alanamu, A. S. (2004) "Ethno-Religious Conflicts in Nigeria: The Current Trends and its Implications" in Africa Conflict Profile, Journal of the Centre for Ethnic and Conflict Studies Uniport Vol.1 No.1

Albert, T.A (2015). The Question of Internally Displaced Persons (IDPs) in Nigeria: A Reflection on Present Realities. Journal of Third World Studies:Vol. 32, No. 1

Asika, N. (1991). Research Methodology in the Behavioural Sciences.lkeja: Longman Plc.

Babbie, E.A. (2007). The Practice of Social Science: Wordsworth Publishing Co. Inc.

Bryman. U. A. (2004). Social Science Research Methods: Fourth Edition, Oxford: Oxford University Press

Burton, J. W. (1990) "Conflict Resolution: The Human Dimension". International Journal of Peace Studies. Available on http://www.gmu.edu/academic/ijps/vol3_1/burton.htm

Burton, J. W. (1990) "Peace Begins at Home. International Conflict: A Domestic Responsibility".International Journal of Peace Studies. Available on http://www.gmu.edu/academic/ijps/vol6_1/Burton.htm

Calderon, M. (2010). Internal Displacement: Recent History, Visions for the Action Ahead .ISP Collection.Paper 838, SIT Graduate Institute. Available at January 2011 from: http://digitalcollections.sit.edu/isp_collection/838.

Du Plessis, A. (2001) "Exploring the concept of identity in world politics", A paper presented at an international conference on Politics of Identity and Exclusion in Africa: From Violent Confrontation to Peaceful Cooperation, Senate Hall, University of Pretoria, South Africa, July.

Effiong, P. (2012). "40 Years Later...The War Hasn't Ended”...in Chima J. K. (eds.), The Nigeria-Biafra War. New York: Cambria Press

Faleti, A. S. (2007). Theories of Conflict, An Introduction to Peace and Conflict Studies in West Africa. Ibadan: Spectrum Books.

Furnivall, J.S. (1948).Colonial Policy and Practice.London: Cambridge University Press. 
Hauss, C. (2003) "Addressing Underlying Causes of Conflict. In Beyond Intractability," July. Available on http://www.beyondintractability.org/m/addressing_underlying_causes.jsp

Human Rights Watch. (2003). Nigeria: The Ogoni Crisis, vol. 7, no. 5, p.41.

Ibeanu, O. (2001a). "State-Making and Internal Population Displacement: Factoring the State into Forced Migration in Nigeria during Military Rule". Africa at Crossroads: Complex Political Emergencies in the 21st Century, UNESCO.

Ibeanu, O. (2001b) "Exiles in Their Own Home: Conflicts and Internal Population Displacement in Nigeria", Journal of Refugee Studies, August Vol. 12, No. 2.

Ibeanu, O. (1998)“Exiles in Their Own Home: Internal Population Displacement in Nigeria. African”. Journal of Political Science Vol. 3 No. 2.

Ikime, O. (1972). The Isoko people: A historical survey. Ibadan University Press.

Integrated Regional Information Networks (2009). "NIGERIA: Focus on internal displacement":http://www.irinnews.org/ report.asp?ReportID=11243\&SelectRegion=West_Africa\&SeectCountry=NIGERIA, accessed 19/5/2015

Integrated Regional Information Networks (2008b). "Bloody week in the Niger Delta": 19 Septemberhttp://www.irinnews. org/Report.aspx?Reportid $=80502$

Ismagilova, R.N. (1978). Ethnic Problems of Tropical Africa: Can They Be Solve; Moacow: Progress Publisher Parson.

Kerlinger, F .N. (1973). Foundation of Behavioural Research. Third edition, New York: Holt Rinehart Winston Inc.

Kunz, E. (1973) 'The refugee in flight: kinetic models and forms of displacement", cited in Ibeanu, O. (1998) "Exiles in Their Own Home: Internal Population Displacement in Nigeria. African", Journal of Political Science Vol. 3 No. 2.

Marker, S. (2003) "What Human Needs Are? In Beyond Intractability", August Available athttp://www.beyondintractabil ity.org/m/human_needs.jsp

Nnoli, O. (1980).Ethnic Politics in Nigeria, Enugu: Fourth Dimension.

Odoemene, A. (2008)“Inter-ethnic relations in Enugu city, Southeastern Nigeria” 1970-2003.Unpublished Ph.D. Thesis, University of Ibadan, Nigeria

Okoye, et al, (Forthcoming). The Federal Character Principle and Political Participation in Nigeria: Interrogating the Relevance of the Policy. African Renaissance

Opukri, C.O \& Ibaba, S.O (2008) "Oil Induced Environmental Degradation and Internal Population Displacement in the Niger Delta", Journal of Sustainable Development in Africa Vol 10, No.1.

Osaghae, E.E. \& Suberu, R.T. (2005). A History of Identities, Violence, and Stability in Nigeria: CRISE Working Paper Queen Elizabeth House: University of Oxford.

Osaghae, E. (1995) Ethnicity and its management in Africa: The democratization link (CASSO Occasional Monograph, No.2). Lagos: Malt house Press.

Otite, O. (2000). Ethnic pluralism, ethnicity and ethnic conflicts in Nigeria.Ibadan: Shaneson Limited.

Plotnicov, L. (1972). Situational ethnicity in Jos cited in Melson, R. \&Wolpe, H. Nigeria: Modernization and the politics of communalism. Michigan: Michigan State University Press.

Reuters, A. (2008) "Civilian Displaced in Nigeria, Delta Camp raids. Retrieved from":

http://af.reuters.com/article/topNews/idAFJOE6B20GO20101203 accessed 5/4/2015.

Rhodes, A.S. (2002). Future: Internally Displaced Persons and the Right to Education. United Nations University for Peace, El Rhode, Costa Rica.

Suhrke, A. (1983) Global Refugee Movement and Strategies of Responses; International Migration Review 5 (3).

Synder, T. (1993) Nationalism and the Crisis of the Post-Soviet State Survival: Vol-35, No1. Moscow.

Tamuno, T. (1999) "On the Niger Delta Question”, Lecture Deliver under the auspices of the Rivers State College of Arts and Science, Port Harcourt and the Rivers State University of Science And Technology, Nkpolu, Port Harcourt. 